\title{
Properties of graphite-stainless steel composite in bipolar plates in simulated anode and cathode environments of PEM fuel cells
}

\author{
RENATA WŁODARCZYK* \\ Department of Energy Engineering, Faculty of Environmental Engineering and Biotechnology, \\ Czestochowa University of Technology, ul. Brzeznicka 60a, 42-200 Czestochowa, Poland
}

\begin{abstract}
The use of a graphite-stainless steel composite as bipolar plates (BP) in polymer electrolyte membrane fuel cells (PEMFCs) has been evaluated. The study covers measurements of mechanical properties, microstructural examination, analysis of surface profile, wettability, porosity and corrosion resistance of the composite. The corrosion properties of the composite were examined in $0.1 \mathrm{~mol} \cdot \mathrm{dm}^{-3} \mathrm{H}_{2} \mathrm{SO}_{4}+2 \mathrm{ppm} \mathrm{F} \mathrm{F}^{-}$saturated with $\mathrm{H}_{2}$ or with $\mathrm{O}_{2}$ and in solutions with different $\mathrm{pH}$ : in $\mathrm{Na}_{2} \mathrm{SO}_{4}+2 \mathrm{ppm}$ $\mathrm{F}^{-}(\mathrm{pH}=1.00,3.00,5.00)$ at $80{ }^{\circ} \mathrm{C}$. The performed tests indicate that the graphite modified with stainless steel can be a good choice to be used as a bipolar plate in PEM fuel cells.
\end{abstract}

Keywords: powder metallurgy; sintering; graphite; bipolar plates; fuel cells; PEMFC

(C) Wroclaw University of Technology.

\section{Introduction}

The polymer electrolyte membrane fuel cells are one of the promising options for portable, stationary power generators, or portable electronic devices [1]. The main components of fuel cells include electrolyte/membrane, electrodes (anode and cathode), bipolar plates (monopolar or bipolar) and end-plates (Fig. 1). Bipolar plates are a key element of PEMs, which account for $40-50 \%$ cost and $60-80 \%$ weight of the whole fuel cell stack [2]. Mass distribution of a generator weighting $24 \mathrm{~kg}$, with a capacity of $33 \mathrm{~kW}$ is shown in Fig. 1A.

Respectively to the mass distribution of the individual components of the cell, the fuel cell should be light and cheap. Graphite is an excellent material for bipolar plates in PEM due to its great corrosion resistance, thermal resistance, high electrical conductivity but the fragile structure of graphite creates difficulty during its manufacturing.

Using BP materials in low-temperature fuel cell production requires consideration of the following factors: density, electrical conductivity, me-

*E-mail: rwlodarczyk@is.pcz.czest.pl

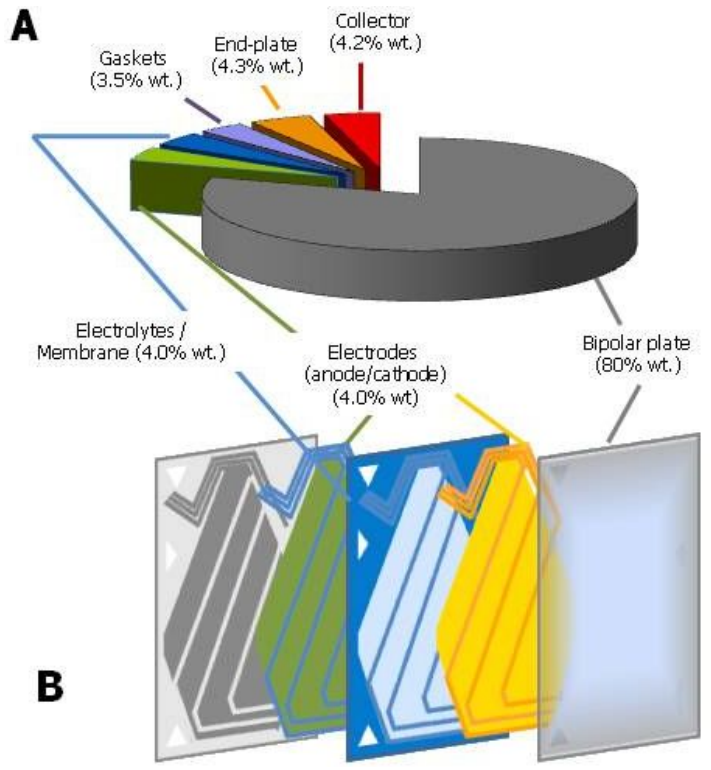

Fig. 1. A - The mass fraction of each component in the cell; B - Construction of a single fuel cell.

chanical properties, corrosion, chemical and thermal stability, gas permeability and manufacturing process [3]. The target material properties, including physical, mechanical and electrical properties, 
reported by DOE (Department of Energy, USA), used in BPs are presented in Table 1. Thin metal sheet is a suitable material for a bipolar plate. The metals used for the construction of a lowtemperature fuel cell cover include nickel, titanium and coatings made based on these metals [47]. In [8], the possibility of using aluminum as a cheaper coating was studied. However, in the working environment of a fuel cell, oxidized aluminum and the products of the process contaminate the membrane. Alloys reported by Nikam et al. $[9,10]$ have high thermal conductivity and electrical and chemical stability as well as easier production with all advantages of copper. On the other hand, highly dense copper and its alloys disqualify these materials in the fuel cells.

The most common material in the group of metallic materials is stainless steel. It presents such qualities as high strength, low gas permeability, diversity of alloying elements and, above all, low production costs. Availability of stainless steel and the low cost of production are its advantages. It can be easily shaped into the form of plates of a thickness as low as 0.2 to $1 \mathrm{~mm}$, suitable for the fabrication of channels in mono- or bipolar covers. The possibility of producing thin plates is associated with a high material density (density of approximately $7.80 \mathrm{~g} \cdot \mathrm{cm}^{-3}$ ), which unfortunately is a disadvantage in these applications. Austenitic steels are usually passivated in the PEM cells working environment [11, 12]. The significant influence of the chemical composition of stainless steel has also been discussed in papers [13-15]. Table 1 shows the properties of steel $316 \mathrm{~L}$ on the basis of literature. According to the information, the 316 stainless steel belongs to a group of wettable materials and the ICR at a pressure of $1.4 \mathrm{MPa}$ is in a range between 70 and $230 \mathrm{~m} \Omega \cdot \mathrm{cm}^{2}$, therefore, it does not apply to DOE requirements $\left(<20 \mathrm{~m} \Omega \cdot \mathrm{cm}^{2}\right)$. Due to the changing environment in the fuel cell operating conditions, steel was tested in solutions of various concentrations of the acid with reference to the presence of fluoride ions from the electrolyte or pure acid. Steel corrosion current density in a sulphuric acid VI varied over a wide range from a few to tens of $\mathrm{mA} \cdot \mathrm{cm}^{-2}$. Comparing the properties of graphite, in terms of its application for the con- struction of low-temperature fuel cell covers, the ICR and corrosion current density meet the requirements of DOE in 2011 (Table 2).

Following the recent reports and features, which are characteristic of carbon-based composites, the next step in the way of material requirements for 2017 will be a study on the construction or use of already existing materials with the following composition: graphite-polymer, carbon fiber-polymer fibers, etc. The most popular materials of bipolar plates, besides graphite, are metallic materials or composites based on carbon: carboncarbon composites [25, 26], carbon-polymer composites [27], and carbon coated metal [27-30]. Metallic bipolar plates provide many advantages such as cheaper material cost, high thermal and electrical conductivity, variety of manufacturing processes and excellent mechanical properties. The advantages and disadvantages of graphite and metallic BP are depicted in Table 2.

In order to improve the mechanical properties of graphite without affecting its corrosion resistance, graphite-SS composite has been proposed.

The composite bipolar plate is a promising alternative to graphite; graphite-stainless steel (SS) composite may greatly improve the mechanical properties of graphite and corrosion resistance of SS in PEM environments. Two main fabrication methods for graphite composite bipolar plates are injection molding and compression molding [3133] used to produce the composite by powder metallurgy technology.

The technology used in this study makes possible to determine the effect of compaction and sintering on the product properties. Finding the relationship between the technological parameters and properties of sinters allows obtaining materials with the desired mechanical properties and resistance to corrosion. The investigations of sintered stainless steel confirmed that the use of suitable parameters of compaction pressure and sintering atmosphere ensures obtaining materials with controllable density, pore and grain size and that a suitable chemical composition of powders allows for obtaining sinters with the desired functional properties $[15,16]$. 
Table 1. Selected properties of the materials most frequently used for the construction of BP.

\begin{tabular}{|c|c|c|c|c|c|}
\hline Materials & $\begin{array}{c}\text { Contact } \\
\text { angle [deg] }\end{array}$ & $\begin{array}{c}I C R \text { at } 1.4 \mathrm{MPa} \\
{\left[\mathrm{m} \Omega \cdot \mathrm{cm}^{2}\right]}\end{array}$ & $\begin{array}{c}I_{\text {corr }} \\
{\left[\mathrm{A} \cdot \mathrm{cm}^{-2}\right]}\end{array}$ & Corrosion environments & Literature \\
\hline $316 \mathrm{SS}$ & - & 125 & approx $400 \times 10^{-6}$ & $1 \mathrm{M} \mathrm{H}_{2} \mathrm{SO}_{4}+2 \mathrm{ppm} \mathrm{HF}, \mathrm{T}=80^{\circ} \mathrm{C}$ & [16] \\
\hline $316 \mathrm{SS}$ & - & approx 250 & $7 \times 10^{-5}$ & $\mathrm{SO}_{4}^{2-}, \mathrm{pH} 2, \mathrm{~T}=80^{\circ} \mathrm{C}$ & [17] \\
\hline 316L SS & - & - & approx $9 \times 10^{-6}$ & $0.5 \mathrm{M} \mathrm{H}_{2} \mathrm{SO}_{4}, \mathrm{~T}=70^{\circ} \mathrm{C}$ & [18] \\
\hline \multirow[t]{2}{*}{ 316L SS } & - & - & $40 \times 10^{-6}$ & $0.1 \mathrm{M} \mathrm{H}_{2} \mathrm{SO}_{4}, \mathrm{~T}=70^{\circ} \mathrm{C}$ & [19] \\
\hline & & & $4 \times 10^{-6}$ & $0.1 \mathrm{M} \mathrm{H}_{2} \mathrm{SO}_{4}, \mathrm{~T}=20^{\circ} \mathrm{C}$ & \\
\hline 316L SS & 73 & 70 & approx $5 \times 10^{-5}$ & $0.5 \mathrm{M} \mathrm{H}_{2} \mathrm{SO}_{4}+5 \mathrm{ppm} \mathrm{F}^{-}, \mathrm{T}=70^{\circ} \mathrm{C}$ & [20] \\
\hline 316L SS & 48 & 230 & $2.4 \times 10^{-5}$ & $1 \mathrm{M} \mathrm{H}_{2} \mathrm{SO}_{4}+5 \mathrm{ppm} \mathrm{F}^{-}, \mathrm{T}=70^{\circ} \mathrm{C}$ & [21] \\
\hline Graphite & - & 2 & $3.8 \times 10^{-6}$ & $0.5 \mathrm{M} \mathrm{H}_{2} \mathrm{SO}_{4}+200 \mathrm{ppm} \mathrm{HF}, \mathrm{T}=20^{\circ} \mathrm{C}$ & [22] \\
\hline Graphite & 80 & 20 & - & - & [23] \\
\hline Graphite & - & 13 & $1.7 \times 10^{-6}$ & $1 \mathrm{M} \mathrm{H}_{2} \mathrm{SO}_{4}+2 \mathrm{ppm} \mathrm{HF}, \mathrm{T}=80^{\circ} \mathrm{C}$ & [24] \\
\hline
\end{tabular}

Table 2. Advantages and disandvantages of graphite and metallic BP.

\begin{tabular}{|c|c|c|c|}
\hline BP material & Advantages & Disadvantages & DOE, 2011 status \\
\hline Poco graphite & $\begin{array}{l}\text { - Corrosion resistance } \\
\text { - Low ICR } \\
\text { - High power density }\end{array}$ & $\begin{array}{l}\text { - Porous } \\
\text { - Poor machinability } \\
\text { - Brittle } \\
\text { - Relatively expensive }\end{array}$ & $\begin{array}{l}\text { - Density }<2.0 \mathrm{~g} \cdot \mathrm{cm}^{-3} \\
\text { - Electrical conductivity }>100 \mathrm{~S} \cdot \mathrm{cm}^{-1} \\
\text { - Contact resistance @ } 1.4 \mathrm{MPa}<20 \mathrm{~m} \Omega \cdot \mathrm{cm}^{2} \\
\text { - Electrical resistivity: low as possible }\end{array}$ \\
\hline Metal & $\begin{array}{l}\text { - None porous } \\
\text { - High electrical and } \\
\text { thermal conductivity } \\
\text { - Good machinability } \\
\text { - Relatively inexpen- } \\
\text { sive }\end{array}$ & $\begin{array}{l}\text { - Corrode in acidic } \\
\text { media } \\
\text { - High ICR }\end{array}$ & $\begin{array}{l}\text { - Corrosion resistance }<16 \times 10^{-6} \mathrm{~A} \cdot \mathrm{cm}^{-2} \\
\text { - Hydrogen permeability }<2 \times 10^{-4} \mathrm{~cm}^{3}\left(\mathrm{~s} \cdot \mathrm{cm}^{2}\right)^{-1} \\
\text { - Thermal conductivity }>10 \mathrm{~W}(\mathrm{~m} \cdot \mathrm{K})^{-1} \\
\text { - Tensil strength }>41 \mathrm{MPa} \\
\text { - Flexural strength }>50 \mathrm{MPa} \\
\text { - Shore hardness }>40 \\
\text { - Hydrophobicity: contact angle }>90^{\circ}\end{array}$ \\
\hline
\end{tabular}

The paper presents the results of investigation on graphite-stainless steel composites, made by powder metallurgy methods, for bipolar plates applications. The plates made from the composites have improved characteristics in comparison to the plates made only of graphite or stainless steel material.

\section{Experimental part}

\subsection{Materials for experiment}

Stainless steel powder and graphite powders were manufactured by Höganäs (Sweden), and by Schunk Kohlenstofftechnik GmbH (Germany), respectively. Water atomized 316LHD (HD - high density) steel and graphite powders were used to prepare a mixture (20\% wt. 316LHD). The mixed powder was compacted at $700 \mathrm{MPa}$ by axial compression and then sintered at a temperature of $1150{ }^{\circ} \mathrm{C} \pm 10{ }^{\circ} \mathrm{C}$ in vacuum. A sample was obtained in the form of tablets of $50 \mathrm{~mm}$ diameter and of about $4.80 \mathrm{~mm}$ thickness. The density, porosity and specific surface area were measured using a mercury porosimeter PoroMaster 33. The particle size distribution of the powders was measured by determining the diameter of the infrared beam (Kamika).

Graphite and SS powders showed a large difference in surface area and thus, the open porosity of the powder particles. Density of 316LHD 
powder was 2 times higher than the density of graphite powder. The distribution size of graphite powder is shown in Table 3. About $97 \%$ of particles have an average particle diameter below $60 \mu \mathrm{m}$. However, the number of particles with an average diameter of less than $10 \mu \mathrm{m}$ is ca. $25 \%$. In SS powder the number of particles with a diameter of less than $60 \mu \mathrm{m}$ is ca. $50 \%$.

The chemical composition of the powders is shown in Table 4 . The chemical analysis was carried out using a spectrometer XRF (Rigaku) model ZSX-Primus II. Fig. 2 shows the morphology of the powders. The graphite powder consists of particles with sharp edges. The powder is contaminated (about $0.05 \%$ ), as observed in the analysis of chemical composition. This small amount of various metals comes from the ash contained in graphite powders [34]. The steel powder, 316LHD, consists of irregularly shaped particles of various sizes. There is a single spherical particle. The powder is chemically uniform.

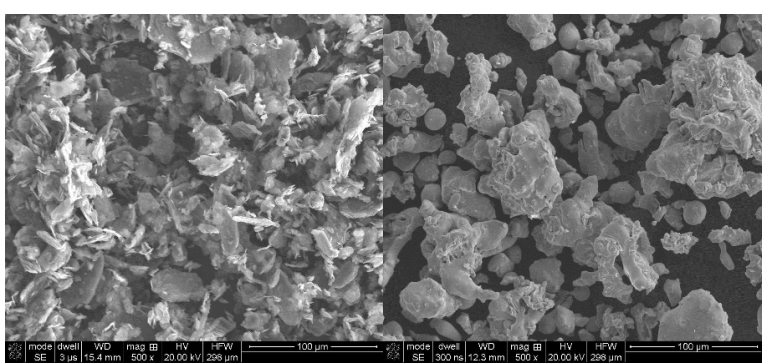

(a)

(b)

Fig. 2. Powders morphology, (a) graphite powder, (b) 316LHD steel powder.

\subsection{Methodology}

Density, porosity and specific surface area measurements of the composite were carried out using a mercury porosimeter PoroMaster 33 supported by Quantachrome Instruments software for Windows.

A compression test was performed on a universal testing machine INSTRON 8501 with an appropriate computer software, equipped with a strain gauge force measurement head, type 2518-103 No. 791 of the UK $\pm 5 \mathrm{kN}$. A pressure test was carried out at a speed of the actuator of $1 \mathrm{~mm} / \mathrm{min}$. During the tensile test, the computer recorded changes in the value of the loading force and the displacement of the actuator of the testing machine.

In order to determine the degree of wetting, $3 \mu \mathrm{l}$ of water was dropped on the surface of the graphite-stainless steel composite. The images of the material with a water drop were analyzed by a MicroCapture microcamera and special software for microimage analysis.

Measurements of interfacial contact resistance (ICR) between the surfaces of diffusion layer (GDL, usually carbon paper) and bipolar plates (BP) were carried out according to the methodology used by Zhang et al. [35]. Techniques of measurement of interfacial contact resistance have been broadly discussed in the studies [36, 37].

The analysis of the geometrical structure of the surface of the sinter was made using a profilographometer PG $1 \mathrm{C}$ working in a modular system TOPO 01. On that basis, the analysis of the surface was carried out, including height feature of profile $\mathrm{R}_{a}$.

During the operation of PEM fuel cells, the ionic exchange membrane may dissolve acidic ions such as $\mathrm{SO}_{4}^{-}, \mathrm{SO}_{3}^{-}$, and $\mathrm{HSO}_{4}^{-}$and $\mathrm{F}^{-}$ions [38]. Products of corrosion of BP materials might poison the catalysts and decrease the efficiency of the fuel cell [39-41]. The working electrode was based on composite, the reference electrode was based on a saturated calomel electrode (SCE), and the auxiliary electrode was based on a Pt wire. Potentiokinetic curves were recorded after 10 seconds from the moment of putting the working electrode in the solution. The electrochemical measurements station was based on CHI 1140 (CH Instruments). Potentiokinetic testing was carried out at a scan rate of $5 \mathrm{mV} \cdot \mathrm{s}^{-1}$.

\section{Results and discussion}

Properties of the obtained composite: graphite $+20 \% 316 \mathrm{~L} / 700$ are presented in Table 5. Steel powder particles were packed during pressing and sintering between particles graphite powder. The consequence of sintering two powders with different properties (density, specific surface area) gave 
Table 3. Properties of powders used for sintering.

\begin{tabular}{|c|c|c|c|c|c|}
\hline & $\begin{array}{l}\text { Density } \\
{\left[\mathrm{g} \cdot \mathrm{m}^{-3}\right]}\end{array}$ & $\begin{array}{l}\text { Specific surface } \\
\text { area }\left[\mathrm{m}^{2} \cdot \mathrm{g}^{-1}\right]\end{array}$ & $\begin{array}{c}<10 \mu \mathrm{m} \\
{[\%]} \\
\end{array}$ & $\begin{array}{c}<20 \mu \mathrm{m} \\
{[\%]} \\
\end{array}$ & $\begin{array}{c}<60 \mu \mathrm{m} \\
{[\%]} \\
\end{array}$ \\
\hline Graphite powder & 2.23 & 7.12 & 24.49 & 51.86 & 96.95 \\
\hline 316LHD powder & 5.67 & 0.25 & 0.64 & 4.27 & 50.48 \\
\hline
\end{tabular}

Table 4. Chemical composition of powders used for sintering (wt.\%).

\begin{tabular}{ccccccccccc}
\hline [\%] & {$[\%]$} & $\mathrm{Si}$ & $\mathrm{Al}$ & $\mathrm{Mo}$ & $\mathrm{Ni}$ & $\mathrm{Ti}$ & $\mathrm{Fe}$ & $\mathrm{Mn}$ & $\mathrm{Cr}$ & $\mathrm{C}$ \\
& & {$[\%]$} & {$[\%]$} & {$[\%]$} & {$[\%]$} & {$[\%]$} & {$[\%]$} & {$[\%]$} & {$[\%]$} & {$[\%]$} \\
\hline \hline Graphite powder $\mathrm{S}=0.0076 \mathrm{P}=0.0004$ & 0.0057 & 0.0027 & 0.0014 & 0.0046 & 0.0092 & 0.014 & - & - & 99.95 \\
316LHD powder $\mathrm{O}=0.20$ & $\mathrm{~N}=0.03$ & 0.25 & 0.213 & 2.62 & 12.25 & - & 67.76 & 0.06 & 16.63 & 0.02 \\
\hline
\end{tabular}

the estimated value of specific surface area of the sinter of $3.29 \mathrm{~m}^{2} \cdot \mathrm{g}^{-1}$.

Table 5. Physical, mechanical and surface properties of composite graphite $+20 \% 316 \mathrm{~L} / 700$.

\begin{tabular}{cc}
\hline & Graphite $+20 \% 316 \mathrm{~L} / 700$ \\
\hline \hline Density $\left[\mathrm{g} \cdot \mathrm{cm}^{-3}\right]$ & 3.886 \\
Hardness HBW 2,5/30/10 & 143.82 \\
Compressive strength [MPa] & 7.9 \\
Porosity [\%] & 10.69 \\
Specific surface area $\left[\mathrm{m}^{2} \cdot \mathrm{g}^{-1}\right]$ & 3.29 \\
Contact angle $[\mathrm{deg}]$ & 124 \\
ICR @ 1.4 MPa $\left[\mathrm{m} \Omega \cdot \mathrm{cm}^{2}\right]$ & 17.0 \\
$\mathrm{R}_{a}[\mu \mathrm{m}]$ & 2.15 \\
\hline
\end{tabular}

\subsection{Surface properties}

The microstructure of sintered graphite steel was porous as a result of the applied manufacturing technology - powder metallurgy method. We can observe the pores of the sizes of mesopores and macropores (Fig. 3). Distribution of pores in the graphite-stainless steel composite is shown in Fig. 4b. Micropores and mesopores determine the size of the inner surface and play an important role in adsorption processes. Macropores act as transport routes for accessing smaller pores (transporting pores) [42]. According to IUPAC (International
Union Pure and Applied Chemistry) the micropores have a diameter of $<0.002 \mu \mathrm{m}$, mesopores have a diameter between $0.002-0.050 \mu \mathrm{m}$ and macropores: $>0.050 \mu \mathrm{m}$ [43]. Knowledge of the nature of porous material brings various possibilities of materials application for diffusion layers, porous membranes, bipolar plates in fuel cells [4446]. The specific surface area of the sintered composite is ca. $3.25 \mathrm{~m}^{2} \cdot \mathrm{g}^{-1}$ (Fig. $4 \mathrm{a}$ ).

The available literature reports that wettability and contact resistance depend on surface geometry [47, 48]. A drop of a liquid, depending on a structure and profile of a rough hydrophobic surface, may be distributed homogeneously, or heterogeneously, leaving a space between the liquid and the solid. The surface roughness is very important from the point of view of surface contact resistance. Uneven, rough surfaces have a small share of contact area and thus, a high ICR value. To get the lower ICR materials for fuel cell covers, they must be polished [49]. Also graphite, as a highly porous material must be properly processed to obtain a minimum value of roughness parameters [50, 51]. Considering the strong influence of surface roughness on the other properties, geometric parameters of the sintered surface structure were analyzed.

During the whole operation, the fuel cell elements were in permanent contact with water (at the cathode side, water was generated and mixed with humidified gases to prevent dehydration of the 

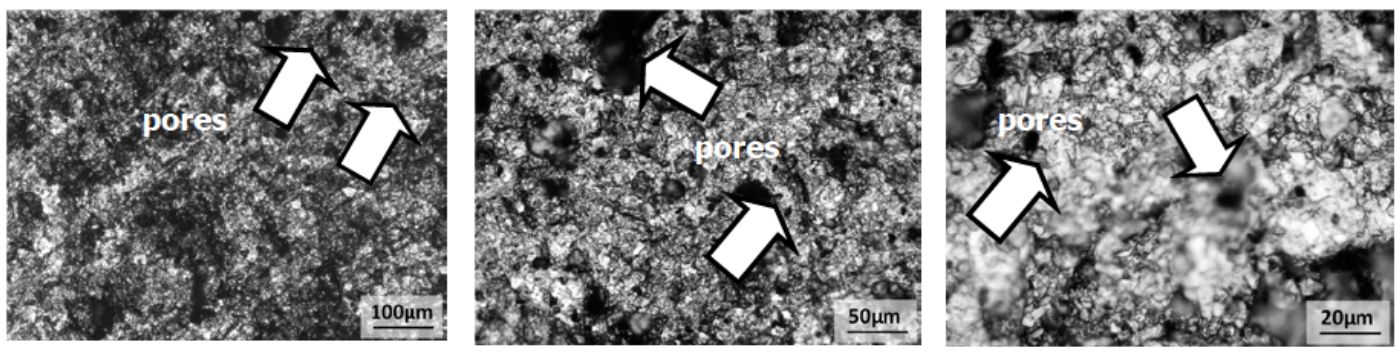

Fig. 3. Microstructures of graphite-stainless steel composite.

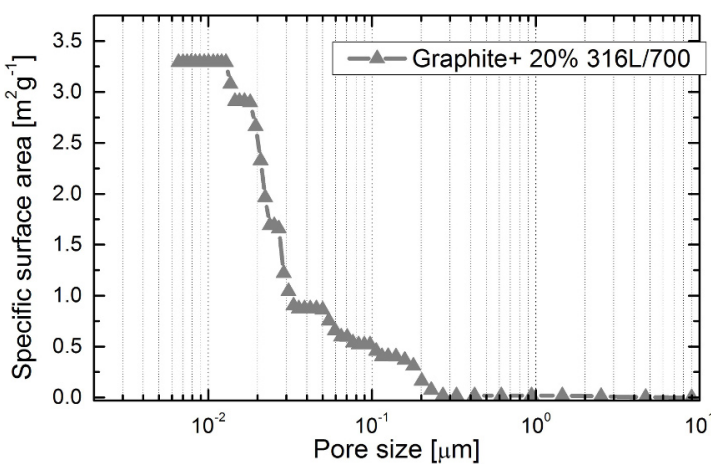

(a)

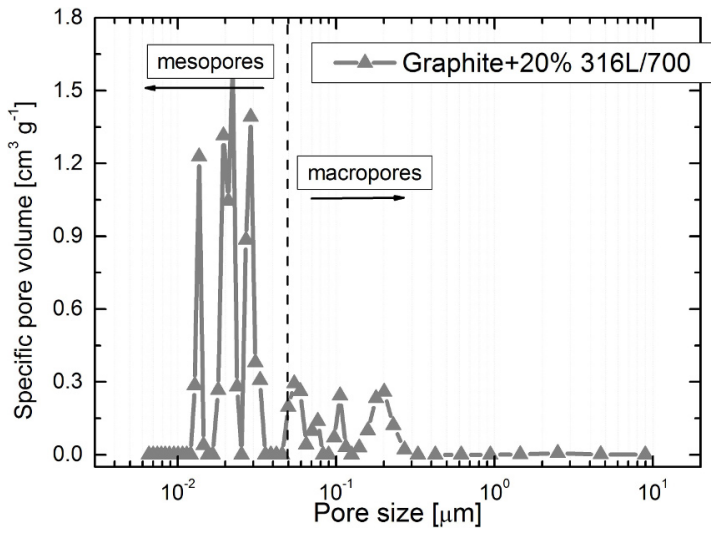

(b)

Fig. 4. Specific surface area (a) and specific pore volume (b) versus pore size in graphite-stainless steel composite.

membrane). If liquid water accumulates in the cell, the cell surface (especially the BP) hinders an access of the reaction gases to the electrodes. Water also accelerates the corrosion of the steel cell components. Accordingly, the degree of moisture in the cell is very important. Because of the cumulated water generated in the fuel cell, the cover materi- als need to have non-wettable surfaces (hydrophobic). The composite is hydrophobic, when the $\Theta$ is higher than $90^{\circ}$ (Table 4). Hydrophobic composite reduces, to some extent, the corrosion rate of the material in the fuel cell operating conditions.

One of the important properties of bipolar plates in PEM fuel cells is low interface contact resistance and high conductivity in order to minimize ohmic losses. According to DOE, the ICR value should be less than $20 \mathrm{~m} \Omega \cdot \mathrm{cm}^{2}$ at $1.4 \mathrm{MPa}$ (Table 5). The ICR values of graphite-316L composite, where stainless steel has a function of compaction force generator (Fig. 5), at $140 \mathrm{~N} \cdot \mathrm{cm}^{-2}$ compaction force is around $17 \mathrm{~m} \Omega \cdot \mathrm{cm}^{2}$. For comparison, the ICR for sintered stainless steel $316 \mathrm{~L}$ was ca. $55 \mathrm{~m} \Omega \cdot \mathrm{cm}^{2}$ with $\mathrm{R}_{a}$ $4.67 \mu \mathrm{m}[16]$.

The electrical sheet resistance is very important for electrical properties of materials for bipolar plates production. Based on reported data, the electrical resistance measured by four-probe technique, gave results of $62 \mathrm{~m} \Omega \cdot \mathrm{cm}$, and $47 \mathrm{~m} \Omega \cdot \mathrm{cm}$, for graphite, and 316L SS, respectively [29]. In this report the electrical resistance of graphite-stainless steel composite was not tested. It can be assumed that graphite modified with SS will have lower electrical resistance in comparison with bare stainless steel. Composite with low electrical resistivity can reduce ohmic losses in fuel cells.

\subsection{Microstructural analysis}

The morphologies of graphite-stainless steel composite are shown in Fig. 6a. Based on the analysis of phase composition in the composite, austenitic phase of $\mathrm{CrFeNi}$, crystallizes in a body-centered cubic cell with $\mathrm{a}=3.591 \mathrm{~nm}$. The 


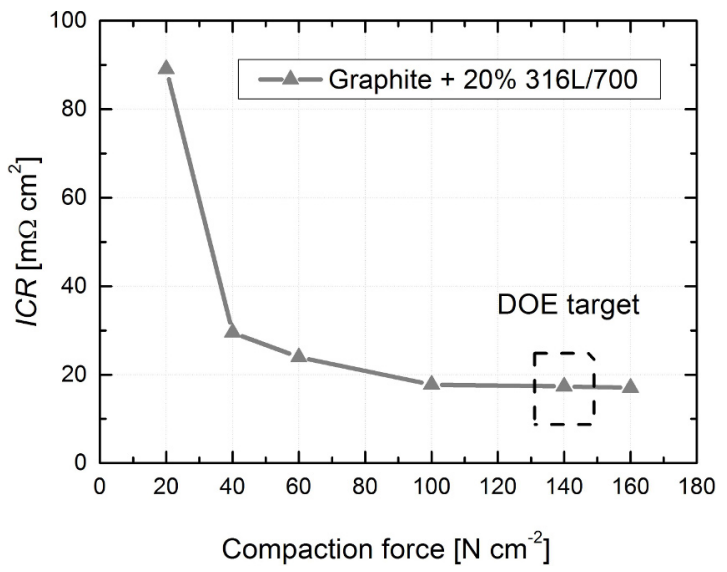

Fig. 5. Interfacial contact resistance for graphitestainless steel composite depending on compaction force.

emerged peaks originate from hexagonal graphite, $\mathrm{a}=\mathrm{b}=0.245 \mathrm{~nm}, \mathrm{c}=0.669 \mathrm{~nm}, \alpha=\beta=90^{\circ}$, $\gamma=120^{\circ}$ (Fig. 6b). Analysis of the chemical composition of a single crystallite of the composite material proved the austenite phase as well as carbon occurrence in the graphite form.

In order to determine the chemical composition of the composite, qualitative EDS (Energy Dispersive Spectroscopy) analysis was used. (Fig. 7).

\subsection{Corrosion resistance}

Fig. 8a shows the potentiokinetic curves of the graphite-stainless steel composite in simulated PEMFC solution (saturated with $\mathrm{H}_{2}$ or with $\mathrm{O}_{2}$ ). The corrosion potential of the sample is equal for both anode and cathode: in anode environment (solution saturated with $\left.\mathrm{H}_{2}\right) E_{\text {corr }}=$ ca. $-0.32 \mathrm{~V}$ vs. SCE, and in cathode environment (solution saturated wtih $\mathrm{O}_{2}$ ) $E_{\text {corr }}=-0.33 \mathrm{~V}$ vs. SCE. In oxygen medium, composites are passivated, which considerably reduces the rate of corrosion process in the active range (see the values of parameters $i_{\text {corr }}$ and polarization resistance $R p$ in Table 6). The dynamic polarization tests (potentiokinetic tests) of graphite-SS composite behavior in PEMFC conditions confirm the formation of a passive area but the passive layer is not stable enough to reduce the current value in the range of $0.0 \mathrm{~V}$ vs. SCE to $0.8 \mathrm{~V}$ vs. SCE up to the value equal to or lower than $i_{\text {corr }}$.

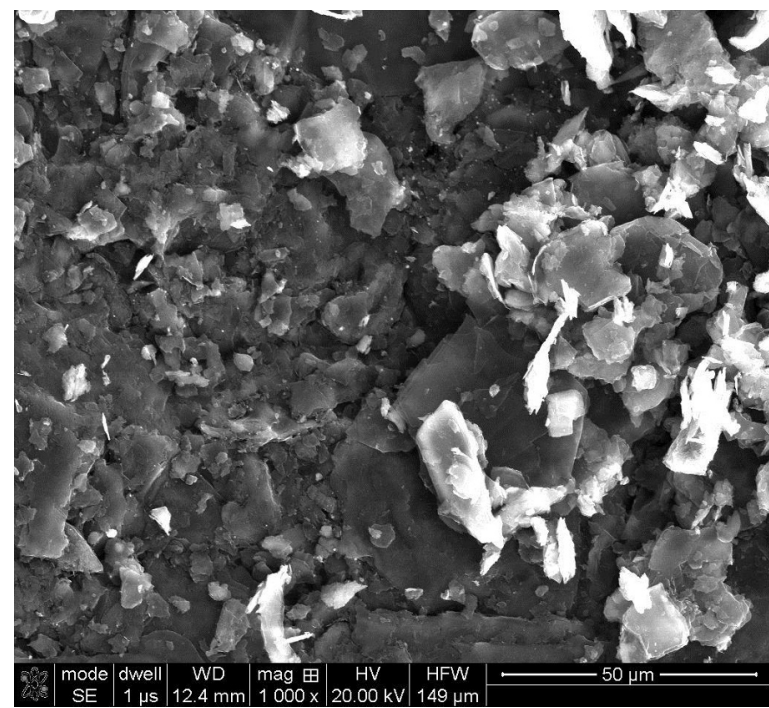

(a)

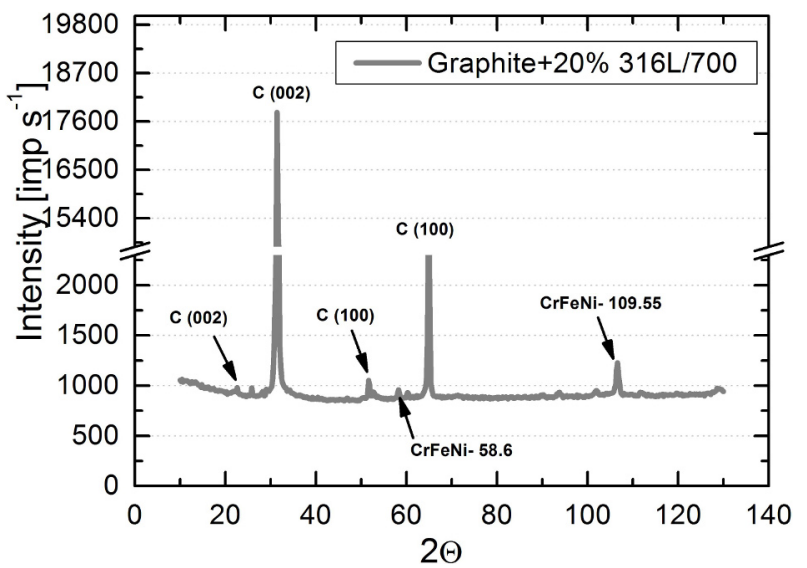

(b)

Fig. 6. SEM analysis (a) and diffractogram (b) of graphite-stainless steel composite.

The behavior of a curve registered in the solution saturated with oxygen shows a passive range of initial passivation at $0.4 \mathrm{~V}$ vs. SCE [52]. Fig. 8a (inset) presents a polarization curve registered for the passivated steel. The $\mathrm{a}-\mathrm{b}$ section corresponds to the area of active metal solubilisation. After reaching the potential of initial passivation $\left(E_{p}, i_{p}\right)$, a passive layer is created on the metal surface. Current density decreases until it reaches the value even lower than $i_{\text {corr }}$ and then it stabilizes. Further increase in the potential does not cause considerable changes in current density until the potential of transpassivation (point d) is reached, i.e. remod- 


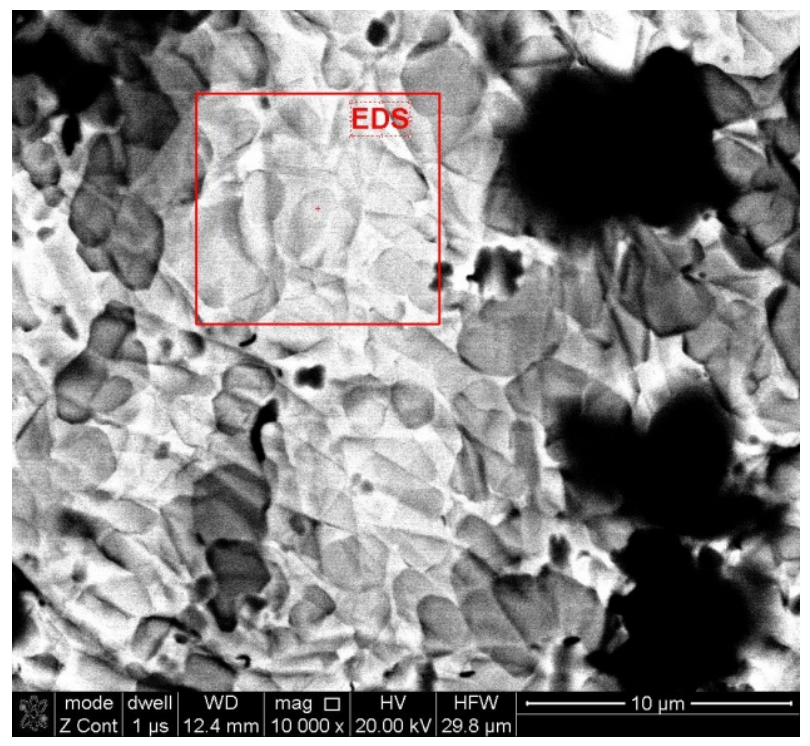

(a)

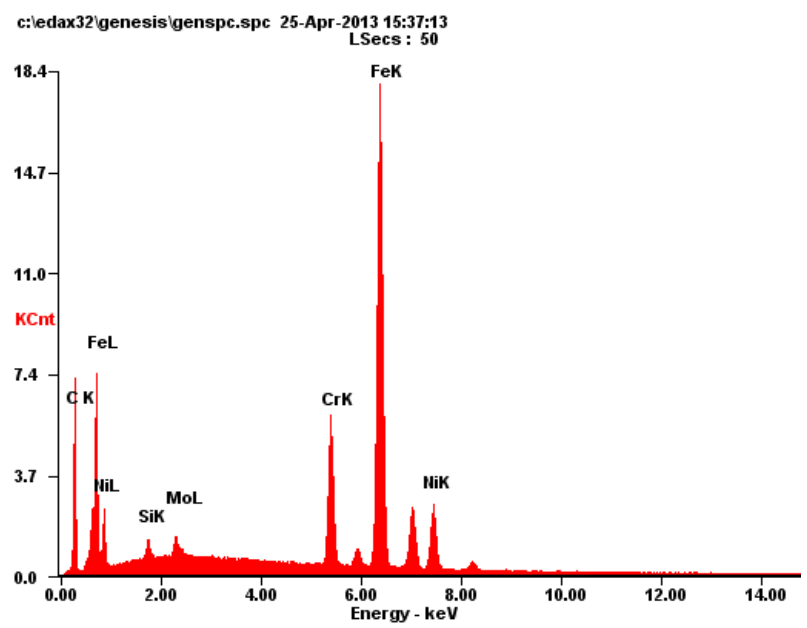

(b)

Fig. 7. SEM image (a) and EDS spectrum (b) of graphite-stainless steel composite.

elling of a passive layer. The dashed line represents potentiokinetic curves observed for non-passivated metal.

Current density versus time can be a measure of material durability at potential values, where the processes of hydrogen oxidation $(-0.1 \mathrm{~V}$ vs. SCE) and oxygen reduction (0.6V vs. SCE) occur (Fig. 8b). One can assume that the lower anode current density at the given potential and the longer time of 'protection' are, the better is corrosion resistance of a material. In order to determine

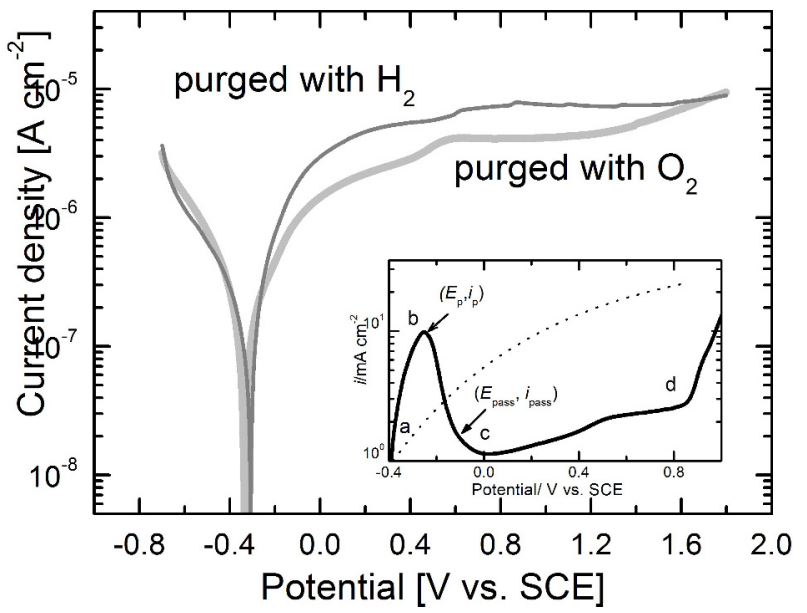

(a)

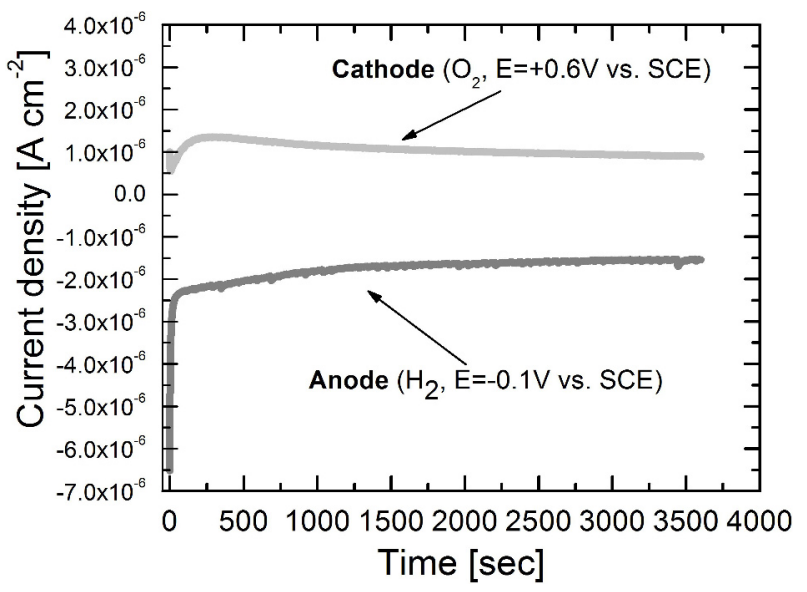

(b)

Fig. 8. Corrosion tests of graphite-stainless steel composite in $0.1 \mathrm{~mol} \cdot \mathrm{dm}^{-3} \mathrm{H}_{2} \mathrm{SO}_{4}+2 \mathrm{ppm} \mathrm{F}$, purged with $\mathrm{O}_{2}$ or with $\mathrm{H}_{2}$, at $\mathrm{T}=80{ }^{\circ} \mathrm{C}$, (a) potentiokinetic curves and (b) potentiostatic curves.

the durability of the composite, chronoamperometric curves for the analyzed graphite-SS composite were registered. The anode current at the beginning of the test was about $-6.5 \times 10^{-6} \mathrm{~A} \cdot \mathrm{cm}^{-2}$ and then it stabilized at $-1.6 \times 10^{-6} \mathrm{~A} \cdot \mathrm{cm}^{-2}$. The obtained chronoamperometric curves for the composite (Fig. 8b) demonstrate a characteristic plateau after exceeding 100 seconds of exposure to the corrosion solution. In case of simulated cathode conditions $\left(\mathrm{O}_{2}\right)$, the current density has stabilized at $1.26 \times 10^{-6} \mathrm{~A} \cdot \mathrm{cm}^{-2}$. This value is almost equal to the value obtained from the potentiokinetic tests 


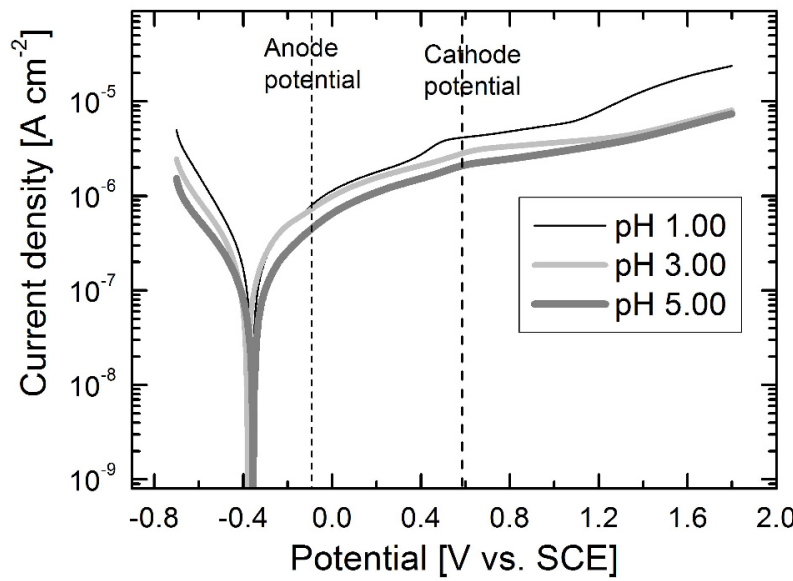

(a)

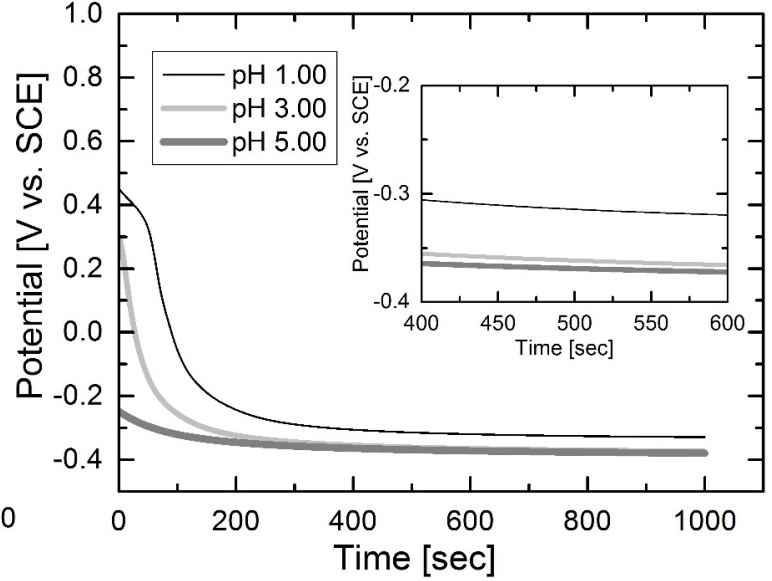

(b)

Fig. 9. Corrosion tests of graphite-stainless steel composite in $0.1 \mathrm{~mol} \cdot \mathrm{dm}^{-3} \mathrm{Na}_{2} \mathrm{SO}_{4}+2 \mathrm{ppm} \mathrm{F}^{-}$at $\mathrm{T}^{2}=80{ }^{\circ} \mathrm{C}$, and $\mathrm{pH}$ values of 1.00, 3.00, and 5.00, (a) potentiokinetic curves (b) open circuit potential.

Table 6. Corrosion parameters obtained from potentiokinetic curves in Fig. 8a.

\begin{tabular}{ccc}
\hline & Anode $\left(\right.$ purged with $\left.\mathrm{H}_{2}\right)$ & Cathode $\left(\right.$ purged with $\left.\mathrm{O}_{2}\right)$ \\
\hline \hline$E_{\text {corr }}[\mathrm{V}]$ & -0.322 & -0.331 \\
$i_{\text {corr }}\left[\mathrm{A} \cdot \mathrm{cm}^{-2}\right]$ & $2.67 \times 10^{-7}$ & $3.48 \times 10^{-7}$ \\
$i$ at $-0.1 \mathrm{~V}$ vs. SCE $\left[\mathrm{A} \cdot \mathrm{cm}^{-2}\right]$ & $2.04 \times 10^{-6}$ & - \\
$i$ at $0.6 \mathrm{~V}$ vs. SCE $\left[\mathrm{A} \cdot \mathrm{cm}^{-2}\right]$ & - & $4.06 \times 10^{-6}$ \\
$R p\left[\mathrm{k} \Omega \cdot \mathrm{cm}^{2}\right]$ & 391 & 434 \\
\hline
\end{tabular}

$\left(4.06 \times 10^{-6} \mathrm{~A} \cdot \mathrm{cm}^{-2}\right)$. On the basis of the potentiostatic tests we can make the following conclusion: the negative current provides cathode protection of BP material and the positive current appears because of the composite corrosion.

In order to check the corrosion resistance of the composite, the potentiodynamic curves were recorded in the solution of the following $\mathrm{pH}$ values: 1.00, 3.00, 5.00 (Fig. 9a). The corrosion potential of the composite has not significantly changed with $\mathrm{pH}$ of the solution. We can observe some differences in current density at anode and cathode potentials. The electrochemical parameters obtained from the potentiokinetic curves are shown in Table 7. The higher the value of polarization resistance, the higher material corrosion resistance. The highest corrosion resistance of the composite was obtained in solution of $\mathrm{pH} 5.00$. Fig. 9b presents open circuit potential versus time in different $\mathrm{pH}$. At free corrosion potential, corrosion oc- curred faster in acidic solution (with $\mathrm{pH} 1.00$ ) than in $\mathrm{pH} 5.00$ solution.

The corrosion properties in anode and cathode environments meets the DOE's 2020 technical targets independently of $\mathrm{pH}$ of solution during operating of PEM fuel cells.

\section{Conclusions}

Except for a number of materials used for bipolar plates, the use of graphite modified with stainless steel seems to be very interesting. Application of the methods of powder metallurgy allows for controlling the density of the manufactured materials as well as their porosity, i.e. characteristics, which, in the case of bipolar plates in fuel cells, affect e.g. material heat capacity, heat and electrical conductivity, resistance to cracking as well as strength and plasticity. The graphite-stainless steel composite made in this investigation showed 
Table 7. Corrosion parameters obtained from potentiokinetic curves in Fig. 9a.

\begin{tabular}{cccc}
\hline & $\mathrm{pH} 1.00$ & $\mathrm{pH} 3.00$ & $\mathrm{pH} \mathrm{5.00}$ \\
\hline \hline$E_{\text {corr }}[\mathrm{V}]$ & -0.361 & -0.374 & -0.353 \\
$i_{\text {corr }}\left[\mathrm{A} \cdot \mathrm{cm}^{-2}\right]$ & $2.52 \times 10^{-7}$ & $1.58 \times 10^{-7}$ & $8.02 \times 10^{-8}$ \\
$i$ at $-0.1 \mathrm{~V}$ vs. SCE $\left[\mathrm{A} \cdot \mathrm{cm}^{-2}\right]$ & $8.35 \times 10^{-7}$ & $7.52 \times 10^{-7}$ & $4.47 \times 10^{-7}$ \\
$i$ at $0.6 \mathrm{~V}$ vs. SCE $\left[\mathrm{A} \cdot \mathrm{cm}^{-2}\right]$ & $3.98 \times 10^{-6}$ & $2.91 \times 10^{-6}$ & $2.13 \times 10^{-6}$ \\
$R p\left[\mathrm{k} \Omega \cdot \mathrm{cm}^{2}\right]$ & 459 & 587 & 995 \\
\hline
\end{tabular}

properties, which met the requirements formulated by the DOE. The density of the composite was below $2 \mathrm{~g} \cdot \mathrm{cm}^{-3}$, ICR at $140 \mathrm{~N} \cdot \mathrm{cm}^{-2}$ below $20 \mathrm{~m} \Omega \cdot \mathrm{cm}^{2}$, and the material was characterized by low corrosion resistance. Based on the analysis of the contact angle, the composite materials were classified as non-wettable (hydrophobic).

The corrosion properties in anode and cathode environments met the DOE's 2020 technical targets. Tests performed proved that the graphite-SS composite can be a suitable choice for the use as a bipolar plate in PEM fuel cells.

\section{Acknowledgements}

I would like to thank Professor Z. Bojar for the opportunity to study in the Department of Advanced Materials and Technology, and Dr. D. Siemiaszko and Dr. D. Zasada for their assistance, and other colleagues from the Department for fruitful discussions.

\section{References}

[1] Kirubakaran A., Jain S., Nema R.K., Renewable and Sustainable Energy Rev., 13 (2009) 2430.

[2] CoOper J.S., J. Power Sources, 129 (2004) 152.

[3] Larminie J., Dicks A., Fuel Cell Systems Explained, Wiley \& Sons, Ltd., 2003.

[4] Show Y., Surf. Coat. Technol., 202 (2007) 1252.

[5] Show Y., Miki M., Nakamura T., Diamond Relat. Mater., 16 (2007) 1159.

[6] Wang S.H., Peng J., Lui W.B., Zhang J.S., J. Power Sources, 162 (2006) 486.

[7] Paulauskas I.E., Brady M.P., Meyer III H.M., BUCHANAN R.A., WALKER L.R., Corr. Sci., 48 (2006) 3157.

[8] El-Enim S.A.A., Abdel-Salam O.E., El-Abd H., AMIN A.M., J. Power Sources, 177 (2008) 131.

[9] Nikam V.V., Reddy R.G., J. Power Sources, 152 (2005) 146.

[10] Nikam V.V., Reddy R.G., Electrochim. Acta, 51 (2006) 6338.

[11] Andre J., Antoni L., Petit J.-P., Int. J. Hydrogen Energy, 35 (2010) 3684.
[12] Kraytsberg A. Auinat M., Ein-Eli Y., J. Powers Sources, 164 (2007) 697

[13] Hodgson D.R., May B., Adcock P.L., Davies D.P., J. Powers Sources, 96 (2001) 233.

[14] Li M.C., Zeng C.L., LuO S.Z., Shen J.N., LiN H.C., CAO C.N., Electrochim. Acta, 48 (2003) 1735.

[15] Geng S., Li Y., Ma Z., Wang L., Wang F., J. Powers Sources, 195 (2010) 2356.

[16] Wang H., Sweikart M.A., Turner J.A., J. Power Sources, 115 (2003) 243.

[17] Yoon W., HuAng X., Fazzino P., REIFsnider K.L., Akkaoui M.A., J. Power Sources, 179 (2008) 265.

[18] Wang Y., Northwood D. O., Electrochim. Acta, 52 (2007) 6793

[19] Wang Y., Northwood D. O., J. Power Sources, 163 (2006) 500.

[20] Fu Y., Lin G., Hou M., Wu B., Li H., HaO L., ShaO Z., YI B., Int. J. Hydrogen Energy, 34 (2009) 453.

[21] LARIJANi M.M., YARI M., Afshar A., JAFARIAN M., Eshghabadi M., J. Alloys and Compounds, 509 (2011) 7400

[22] Hung Y., El-Khatib K.M., Tawfik H., J. Applied Electrochemistry, 35 (2005) 445.

[23] Yan X., Hou M., Zhang H., Jing F., Ming P., Yi B., J. Power Sources, 160 (2006) 252.

[24] NAm D.-G., LeE H.-C., J. Power Sources, 170 (2007) 268

[25] M. Wissler, J. Power Sources, 156 (2006) 142.

[26] Chung C.-Y., Chen S.-K., Chin T.-S., Ko T.-H., Lin S.-W., Chang W.-M., Hsiao S.-N., J. Power Sources, 186 (2009) 393.

[27] Zhu J., Wang X., Guo L., Wang Y., Wang Y., Yu M., LAU K., Carbon, 5 (2007) 2547.

[28] LariJani M. M., YARI M., Afshar A., Jafarian M., Eshghabadi M., J. Alloys and Compounds, 509 (2011) 7400

[29] Fukutsuka T., Yamaguchi T., Miyano S.-I., Matsuo Y., Sugie Y., Ogumi., J. Power Sources, 174 (2007) 199

[30] Wind J., Spah R., Kaiser W., Bohm G., J. Power Sources, 105 (2002) 256

[31] KAKATI B.K., YAMSANI V.K., DhathathreYAN K.S., Sathiyamoorthy D., Verma A., Carbon, 47 (2009), 2413.

[32] Fu Y., Lin G., Hou M., Wu B., Shao Z., Yi B., Int. J. Hydrogen Energy, 34 (2009) 405. 
[33] Dhakate S.R., MathuR R.B., KaKati B.K., DHAMI T.L., Int. J. Hydrogen Energy, 32 (2007), 4537.

[34] Yuan W., Tang Y., Yang X., Wan Z., Applied Energy, 94 (2012) 309.

[35] Zhang L., LiU Y., Song H., Wang S., Zhou Y., Hu S.J., J. Power Sources, 162 (2006) 1165.

[36] WhodARCZyK R., Materials Science Forum, 706-709 (2012), 1047.

[37] WŁodarczyk R., Dudek A., KobyŁecki R., Bis Z., Corrosion Resistance, Chapter 9: Corrosion resistance of composites based to graphite used as bipolar plates in fuel cells, H. Shih - INTECH, Croatia, 2012, p. 189.

[38] Lee S.-J., Huang C.-H., Lai J.-J., Chen Y.-P., J. Power Sources, 131 (2004) 162.

[39] WŁodarczy K R., Wrońska A., Arch. Metall. and Mater, 2013, DOI: 10.2478/v10172-012-0156-7.

[40] WŁodarczyk R., Dudek A., Nitkiewicz Z., Arch. Metall. and Mater, 56 (1), 2011, 182.

[41] WŁODARCZYK R., KACPRZAK A., KobYŁECKI R., BIS Z., Functional Materials Letters, DOI: 10.1142/S1793604713500239.

[42] WŁodarczyK R., in press in Arch. Metall. and Mater.

[43] www.iupac.org, website, 2013.
[44] LeE H.-K., PARK J.-H., Kim D.-Y., LeE T.-H., J. Power Sources, 131 (2004) 200.

[45] Gostick J. T., Fowler M. W., Ionnnidis M. A., Pritzker M. D., Volfkovich Y.M., SAKars A., J. Power Sources, 156, (2006) 375.

[46] Molin S., GAZDA M., JASInSKi P., Solid State Ionics, 181 (2010) 1214.

[47] Kim D.-K., LEE D.-G., LEE S., Metallurgical and Materials Transactions 32A, (2001) 1111.

[48] Hakiki N.E., J. Applied Electrochemistry, 40 (2010) 357.

[49] Kraytsberg A., Auinat M., Ein-Eli., J. Power Sources, 164 (2007) 697.

[50] Barber M., Sun T.S., Petrach E., Wang X., Zou Q., J. Power Sources, 185 (2008) 1252.

[51] Cunningham B.D., Baird D.G., J. Power Sources, 168 (2007) 418.

[52] WŁodARCZYK R., DUdEK A., Steel Research International, 81(9), 2010, 1288. 